\title{
内科学の展望（第16回）造血器腫瘍の治療 最近の進歩
}

司会 愛知県がんセンター 太田和雄

\section{V.リンパ性増殖性疾患}

1）悪性リンパ腫の治療と予後因子

\author{
国立がんヒンター病院薬物療法部 下山正德
}

腫瘍細胞の由来に従って悪性リンバ腫を分類す ると疾患の本質が明らかになり, 予後因子, 病態, 病因, 治療効果については日本人と欧米白人のも のに大きな違いがあることが明らかとなった。リ ンパ節に原発するホジキン病の腫瘍細胞の由来 は，未だ明らかではない。曾て，ホジキ病が Reed-Sterunberg型巨細胞で診断された時代で は, 日本のホシキン病は九州地区に多く，予後も 悪いものであったが，去の3 割から7割近くは成 人T細胞白血病・リン八腫 (ATL) や多形細胞型 のT，Bリンパ腫と誤診していた事が明らかに なった ${ }^{1) 51}$.ホジキン病は欧米白人に多く, 日本で はまれな疾患であり，地域集積性もない。疾患概 念が明らかでなく，腫瑒細胞の由来も明らかでな いホジキン病を基本にして, 真のリンパ腫を非ホ シキンリンパ腫として一括するのは理に叶った事

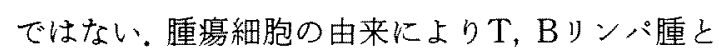
して，おの㧍のを独立して扱うべきである。

日本にはТリンパ腫が多く，Bリンパ腫が少な いといら特徵がある.Bリンパ腫では, 予後の良い 汇胞性リンパ腫や慢性Bリンパ性白血病群が少な

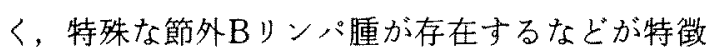
的である ${ }^{6)}$. 全国調査の結果より，Tリンパ腫とB リンバ腫の頻度に地域差があり, その原因はレト ロウイルスが関与するATLによっている6).一方,
欧米白人の非ホジキンリンパ腫の殆どはBリンパ 腫であり，しかも予後の良い沪胞性リンパ腫がそ の大半を占める。我々は，こ5した特徵を持つ日 本人の悪性りンパ腫患者の診療を行らわけである から, 予後因子, 治療法, 治療結果などについて 欧米の論文を鵜吞みにしてはいけない，日本人の 悪性リンパ腫の予後因子や治療研究の結果に基づ いて，よい治療を適用することが必要である。

\section{Bリンパ堹}

\section{1) 予後因子}

Bリンパ腫の予後因子として推計学的に有意な bのは, (1)病理診断, (2)原発栄, (3)病期分類, (4) 年令, (5)血清総蛋白值などである7). この内, $\mathrm{p}<$ $0.01 て ゙$ risk比が2.5以上の最も重要な予後因子は 病理診断, 原発栄, 病期分類である。

\section{2）治療指針}

この予後因子と従来からの臨床知見から, 治療 法の選択基準は下記の様になる。

a）手術療法が適応となるBリンパ腫

胃原発のBリンパ腫で病期Iのものは, 手術のみ で治癒する。術前のCT検査, 超音波診断でリンパ 節転移が無い場合は手術の絶対的適応である。術 後,リンパ節転移が陽性であれば，直ちに薬物療 法を行う。

腸管原発のBリンパ腫で病期 $\mathrm{I}$ のものは, 手術

Review on Internal Medicine (1988) Recent Progress in Treatment of Haematological Malignancies

V. Lymphoproliferative Disease. 1) Recent results of chemotherapy and major prognostic factors in patients with T-cell lymphoma, B-cell lymphoma and Hodgkin's disease

Chairman : Kazuo OHTA, Aichi Cancer Centel

Masanori Shimoyama, National Cancer Center Hospital, Hematology-Oncology and Clinical Cancer Chemotherapy Division, Tokyo 
の適応である。病期 Iであっても，術後の病理猃断 がバーキットリンパ腫とか予後不良群 (unfavorable）の場合は薬物療法を直ちに行う.

甲状腺の B リンパ腫で病期 I のものも，手術の 適応となる、しかし，その殆どは，橋本病を基礎 疾患として発生してくるし，気管に直接浸潤して いることがあるので，手術上り放射線療法の方が 良いことがある。

病期IIであっても，リンパ節原発のものや，そ の他の臓器原発のものは例外を除き, 手術療法の みで治癒させることは出来ない。一部は放射線療 法で，多くは最初から薬物療法を適用させた方が よい.

b）放射線療法

一般的に病期 I またはII の沪胞性リンパ腫（完 全型かそれに近いもの）は症状，病態に合わせて 放射線療法を行う。汇胞性リンパ腫は鼠径部に初 発するものが多い，圂径部のリンパ腫を郭清する と，下肢に浮腫がくるので，生検も最小限にする。 頭䅡部領域に初発する病期 I およびIIのBリン 八腫は，今までは放射線療法が行われることが多 かったし，耳鼻科領域では，それが通念化してい た。しかし，最近の分析では，放射線療法で高率 に治癒させ得るのは，ワルダイエル輪原発の病期 I のBリンパ腫で，特に汇胞性リンパ腫の場合で は90\%以上が長期生存する。しかし、びまん性Bリ ンハ腫の 5 年生存率は50\%以下と低いので，薬物 療法で治療すべきである.鼻腔原発のリンパ腫は, 2：3でTリンパ腫の方が多い，従来は放射線療 法で治療されたが，予後はよくないので，薬物療 法で初めから治療した方がよい。

甲状腺原発のBリンパ腫で病期 I の場合も放射 線療法で治癒することが多い，しかし，病理が予 後不良群の場合は最初から，薬物療法で治療す心゙ きである。

その外の蔵器原発のBリンパ腫や、リンパ節原 発のBリンパ腫は，たと文病期 I であっても，放射 線療法で治瘾は期待しがたい，薬物療法の適応で ある。

c）薬物療法

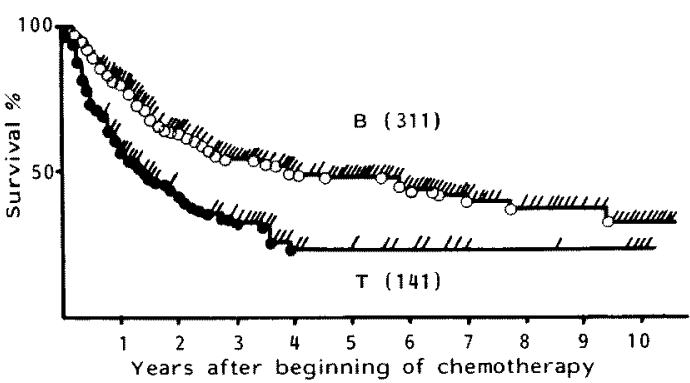

図 1。成人Bリンバ腫患者とTリンパ腫患者で初回治 療として化学潦法をうけた場合の生存曲線

最近の併用化学療法の治療成績の向上はめざま しい，特に病期 II ではCR率は $90 \%$ 以上であり，そ の殆どは無再発で長期生存し，治癒することが期

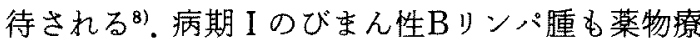
法を適用してょく，従来の放射線療法より長期生 存率は高いが，比較試験は行われていない。病期 III以上は薬物療法の適応で，50\%は治瘾が期待さ れる，薬物療法の内容については後述する，薬物 療法は進行期のBリンパ腫を対象としているため に，他の治療法の適応外の症例を一括して引き受 ける宿命を負わされている，そのためにも治瘑る 目指した薬物療法の適応となるBリンパ腫の病態 は何か，治癒が難しい病態は何かなどを明らかに し，新しい治療法を開発する目標を明らかにする ことが必要である。それを明らかにするものは予 後因子解析である。

（1）化療患者の予後因子

初回治療として化学療法を受けた成人のBリン パ腫311例，Tリンパ腫141例（図 1)を対象とした。 Bリンパ腫患者の予後因子としてCox比例ハザー ドモデルによる多变量解析で有意なものは，(1)病 理部断, (2)節外藏器病变数, (3)病期分類, (4)初回 化学療法の種類，(5)血清総蛋白値，(6)腸の病変な

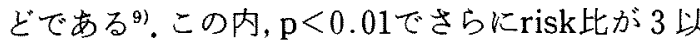
上の最も重要な予後因子は病理診断, 節外臟器病 变数，病期分類である(表 1)。これらは欧米の非 ホジキンリンパ腫患者の重要な予後因子として, 既に報告されてきたものである。欧米の非ホジキ ンリンパ腫の 9 割はBリンパ腫であるので，この 

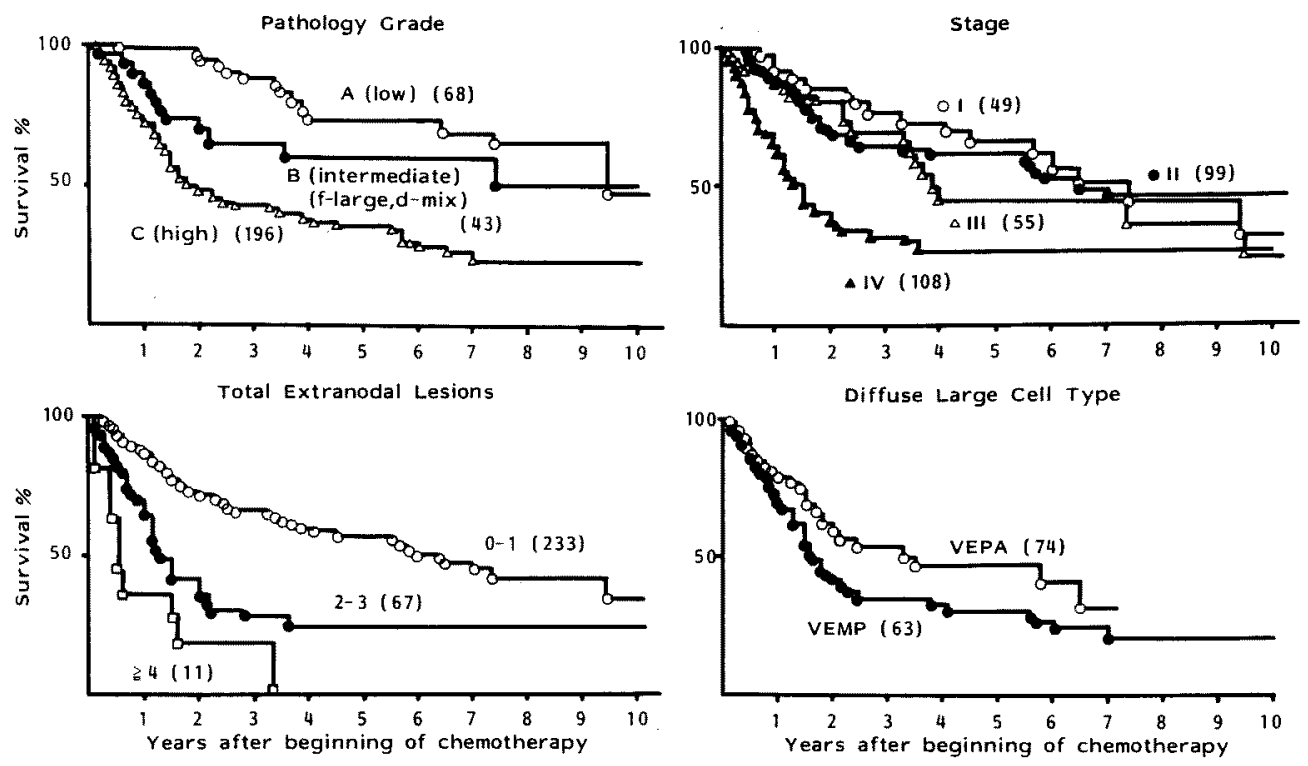

図 2、Bリンパ稙化療患者の重要な予後因子別生存曲線

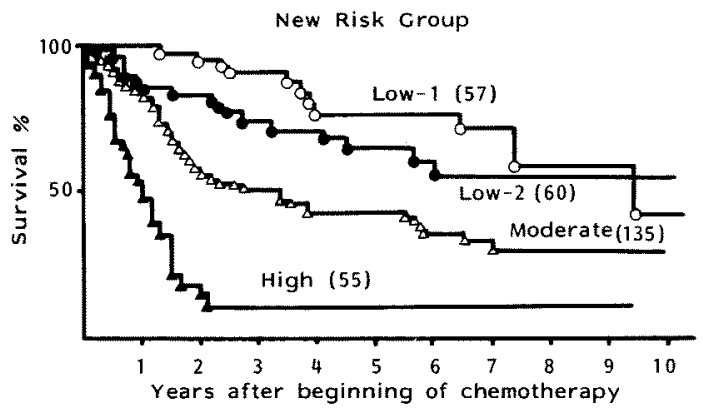

困 3.Bリンパ腫化療患者の重要な予後因子に基つくく 新しいrisk groupの生存曲線（表 1 参照）

結果は当然であるかもしれない.

今回の分析で, 初回化学療法の種類がBリンパ 腫患者の予後因子となったことは注目される，薬 物療法の内容は後述するが, doxorubicin(ADM) を含む併用化学寮法 (VEPAまたはVEPA-M療 法8) 13) ) はそれを含まない併用化学療法 (VEMP, COP, COPP) より延命効果が著しく（図 2)，そ のrisk比は1.6である。これは時代の差を考慮した 多変量解析でる有意であるので，Bリンパ腫に対 するADMの有用性は，この解析からも明らかで ある9).
表 1. Risk group(化療B-lymphoma：307例)

\begin{tabular}{|c|c|c|c|c|c|c|c|}
\hline & 病理 $* 1$ & 病期 & $\begin{array}{c}\text { 節外 } \\
\text { 践器数 }\end{array}$ & $\underset{\text { Ratio }}{\text { Hazard }}$ & 患者 & $\begin{array}{l}\text { Risk*2 } \\
\text { Group }\end{array}$ & $\begin{array}{c}8 \text { 年 } \\
\text { 生存率 }\end{array}$ \\
\hline 1 & Low & 1 & 0,1 & 0.1077 & 9 & \multirow{4}{*}{$\begin{array}{c}\text { Low-1 } \\
(57)\end{array}$} & \multirow{4}{*}{$58.8 \%$} \\
\hline 2 & Low & 2 & 0,1 & 0.1768 & 18 & & \\
\hline 3 & 1 & 1 & 0,1 & 0.2440 & 8 & & \\
\hline 4 & Low & 3 & 0,1 & 0.2903 & 22 & & \\
\hline 5 & I & 2 & 0,1 & 0.4005 & 17 & \multirow{4}{*}{$\begin{array}{c}\text { Low-2 } 2 \\
(60)\end{array}$} & \multirow{4}{*}{$56.1 \%$} \\
\hline 6 & Low & 4 & 0,1 & 0.4762 & 6 & & \\
\hline 7 & High & 1 & 0,1 & 0.5527 & 32 & & \\
\hline 8 & I & 3 & 0,1 & 0.6572 & 5 & & \\
\hline 9 & High & 2 & 0,1 & 0.9071 & 63 & \multirow{7}{*}{$\stackrel{\mathrm{M}}{(135)}$} & \multirow{7}{*}{$30.6 \%$} \\
\hline 10 & Low & 4 & 2,3 & 1.0294 & 11 & & \\
\hline 11 & I & 4 & 0,1 & 1.0785 & 4 & & \\
\hline 12 & High & 3 & 0,1 & 1.4886 & 26 & & \\
\hline 13 & Low & 4 & $\geq 4$ & 2.2254 & 2 & & \\
\hline 14 & I & 4 & 2,3 & 2.3316 & 9 & & \\
\hline 15 & High & 4 & 0,1 & 2.4429 & 20 & & \\
\hline 16 & High & 4 & 2,3 & 5.2812 & 46 & \multirow{2}{*}{$\underset{(55)}{\text { High }}$} & \multirow[t]{2}{*}{$11.4 \%$} \\
\hline 17 & High & 4 & $\geq 4$ & 11.4171 & 9 & & \\
\hline Risk比 & 5.1 & 4.4 & 4.7 & 106 & & 12.2 & \\
\hline
\end{tabular}

*1 Low, low grade; I, f-large, d-mixed ; High, others.

*2 M, moderate risk.

（2）化療患者のrisk グループ

Bリンパ腫化療患者の重要な予後因子である上 記の 3 日子と治療法別の生存曲線を図 2 亿示す。 
この 3 因子の単純組合せで36通りの患者群が出来 るが，理論的に有り得ない組合せも生ずる。すな わち, 節外臓器病変が 2 以上の場合は病期はすべ てIVとなり，それ以外の病期との組合せは有り得 ない，従って，実際には表 1 に示すよらな17通り の組合せが出来る，各組合せについてCoxモデル から求められる死亡に対する危険率（hazard ratio）を小さいものから順に並べると，新しい risk groupが出来る。年生存曲線を図 3 に示す がこれらのデータはBリンパ腫患者を治療する とき，治療前の所見からその予後を推測するのに 有用である。また，high riskの患者群は難治性で， 新しい薬物療法の開発の対象になる. moderate riskでは完全寛解後の再発を防ぐ治療法の導入が 必要である。

\section{Tリンパ腫}

\section{1) 予後因子}

Tリンパ隀の予後因子として有意なるのは，(1) 病変部の数, (2)LDH値, (3)血清総蛋白値, (4)一般 状態 (performance status: PS)，(5)皮虞病変の 有無である。注意すべき点は，Bリンパ腫の重要な 予後因子である病理, 病期, 原発巣はTリンパ腫の 有意な子後因子ではないことである，さて，p< 0.01でrisk比が3.0以上の最も重要な予後因子は 病変部の数, $\mathrm{LDH}$ 值, 血清総蛋白値である。

\section{2）治療指針}

これらの予後因子と従来からの臨床治験から， 治療法の選択基準は下記の様になる。

a) 放射線治療

鼻腔原発の病期 I のTリンパ腫は放射線療法, 菌状息肉症の前息肉期はステロイド軟膏および methoxsalen内服後 $2 \sim 4$ 時間後の長波長紫外線 照射（PUVA）療法, 扁平浸潤期はPUVA療法, $\beta$ トロンによる放射線療法が奏効する。

\section{b) 薬物療法}

上記以外はすへて，薬物療法か，薬物療法を中 心とした集学的治療が必要である。薬物療法の内 容については後述する，Tリンパ腫はBリンパ腫 より難治性である。薬物療法は難治性のTリンパ 腫を対象としているために，治癒を目指した薬物
療法の適応となるТリンパ腫の病態は何が, 治癒 が難しい病態は何かなどを明らかにし，新しい治 療法を開発する目標を明らかにすることが必要で 㐫る。そ机を明らかにするものは予後因子解析で ある。

（1）化療患者の予後因子

Tリンパ腫化療患者の予後因子を多变量解析で 分析した結果, 有意な予後因子は，(1)病変部の数, (2)LDH値，(3)血清総蛋白值，(4)費血の有無，(5)皮 膚病変の有無, (6)治療開始年である ${ }^{9}$.これらはB リンパ腫の予後因子とは全く異なっている点に注 目しなければならない。亦，一般状態 (performance status : PS) はTリンパ腫の重要な予後因 子として指摘されたものであるが，病変部の数と 極めて相関度が高く，かつPSより病变部の数の方 が有意であることが判明した，化学療法の内容が Bリンパ腫ほど重要な予後因子にはなっていない ことは，Tリンパ腫に対する有効な治療法が確立 していないことを物語っている。しかし，既に報 告したように ${ }^{9121}$, Тリンパ腫の一部，すなわち， 通常のTリンパ腫は化学療法が有効で長期生存す るものが多いが，成人下細胞白血病・リンパ腫

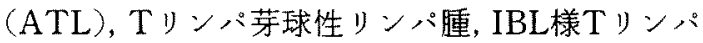
腫の予後は悪い(図 4). 多変量解析で検出された

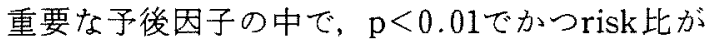
2.5 以上である予後因子は, 上記の(1)一 (3)の 3 因子 である。これらはBリンパ腫の重要な予後因子と 全く異なっている事が注目される。

（2）化療患者のrisk グループ

最重要な予後因子である病変部の数, $\mathrm{LDH}$ 值, 血清総蛋白値の 3 因子の生存曲線を図 4 K示し た。この 3 因子を組み合わせると, 表 2 に示すよ らな18通りの患者群が出来る。この各群の患者の 死亡に対する危険率 (hazard ratio)を小さいるの から順に並べて新しいriskグループを作る。これ らのグループの生存曲線を図 5 に示すが，これら のデータはTリンパ腫の患者を化学療法で治療す る場合の予後を推定するための指針として用いる ことが出来る. moderate riskやhigh riskの患者 群は現在の治療法では難治性であり，新しい治療 

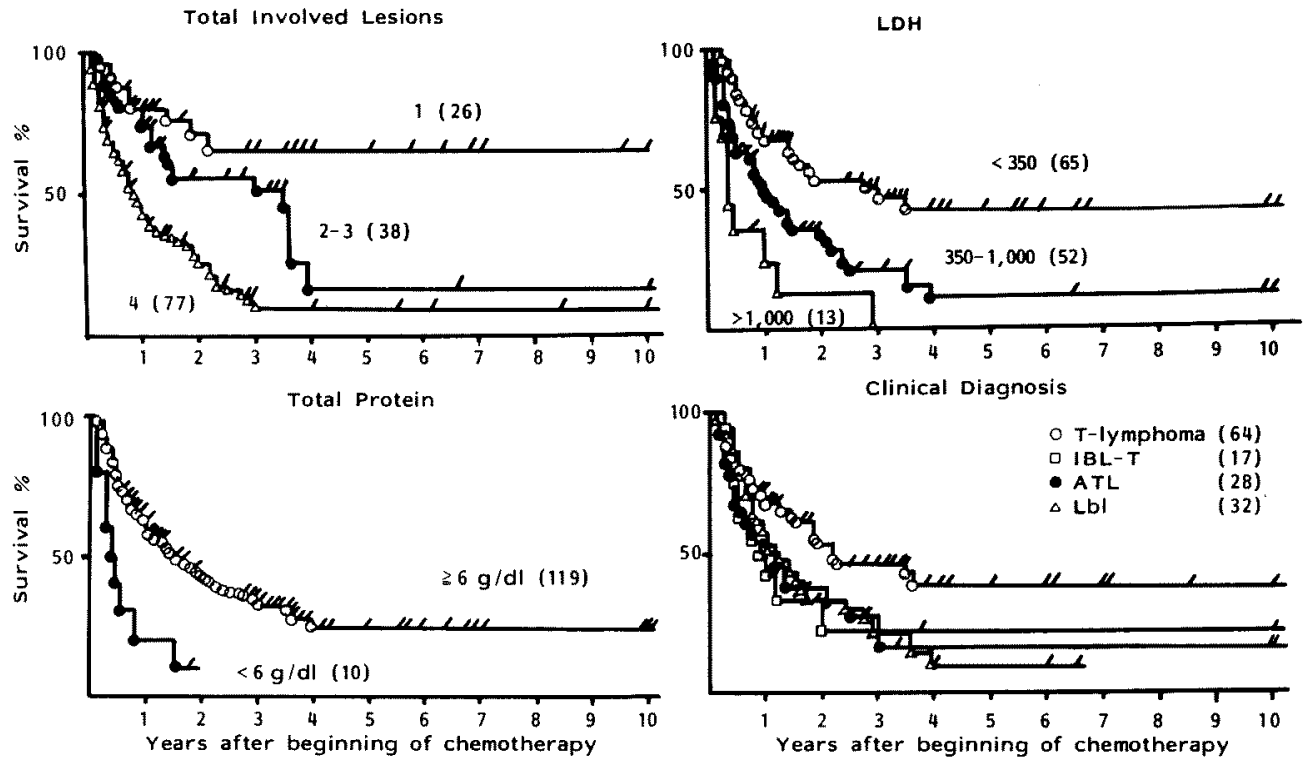

図 4、Tリンパ腫化療患者の重要な予後因子別生存曲線

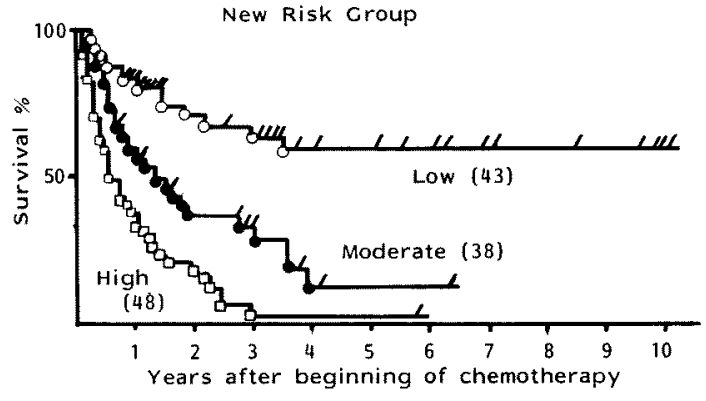

图 5、Tリンパ重化療患者の重要な予後因子別生存曲 線とそれに基づく新しいrisk groupの生存曲線（表 2 参照)

法を開発しなければならない。

III. ホジキン病の予後因子

日本のホジキン病は診断に問題があったことも あって，予後因子は調べられていない，欧米の木 ジキン病の予後因子は病期，B症状，病理㟝断，巨 大な縦隔腫瘍，血沈，病変の数などである.

\section{IV. 薬物療法}

紙面の都合で，各治療法での抗癌剤の組合せ， 投与法，投与量の詳細は省略する，別の文献6)18119) を参照してほしい。
表 2. Risk group(化療T-lymphoma：129例)

\begin{tabular}{c|l|c|c|c|r|r|r}
\hline & $\mathrm{TP}$ & $\begin{array}{c}\text { 全病変 } \\
\text { 就 }\end{array}$ & $\mathrm{LDH}$ & $\begin{array}{c}\text { Hazard } \\
\text { Ratio }\end{array}$ & $\begin{array}{c}\text { 患者 } \\
\text { 数 }\end{array}$ & $\begin{array}{c}\text { Risk } \\
\text { Group }\end{array}$ & $\begin{array}{c}6 \text { 年 } \\
\text { 生存率 }\end{array}$ \\
\hline 1 & $\mathrm{~N}$ & 0,1 & $\mathrm{~N}$ & 0.2245 & 18 & $\mathrm{LP}$ & $59.2 \%$ \\
2 & $\mathrm{~N}$ & 0,1 & $\mathrm{H}$ & 0.3808 & 4 & $(43)$ & \\
3 & $\mathrm{~N}$ & 2,3 & $\mathrm{~N}$ & 0.4983 & 21 & & \\
\hline 4 & $\mathrm{~N}$ & 0,1 & $\mathrm{EN}$ & 0.6458 & 0 & & \\
5 & Low & 0,1 & $\mathrm{~N}$ & 0.7292 & 1 & & \\
6 & $\mathrm{~N}$ & 2,3 & $\mathrm{H}$ & 0.8451 & 10 & $\mathrm{MR}$ & $12.8 \%$ \\
7 & $\mathrm{~N}$ & 24 & $\mathrm{~N}$ & 1.1058 & 23 & $(38)$ & \\
8 & Low & 0,1 & $\mathrm{H}$ & 1.2367 & 1 & & \\
9 & $\mathrm{~N}$ & 2,3 & $\mathrm{EH}$ & 1.4333 & 3 & & \\
\hline 10 & Low & 2,3 & $\mathrm{~N}$ & 1.6183 & 0 & & \\
11 & $\mathrm{~N}$ & $\geq 4$ & $\mathrm{H}$ & 1.8755 & 32 & & \\
12 & Low & 0,1 & $\mathrm{EH}$ & 2.0975 & 0 & & \\
13 & Low & 2,3 & $\mathrm{H}$ & 2.7447 & 1 & $\mathrm{HR}$ & $3.1 \%$ \\
14 & $\mathrm{~N}$ & $\geq 4$ & $\mathrm{EH}$ & 3.1809 & 8 & $(48)$ & \\
15 & Low & $\geq 4$ & $\mathrm{~N}$ & 3.5914 & 2 & & \\
16 & Low & 2,3 & $\mathrm{EH}$ & 4.6551 & 0 & & \\
17 & Low & $\geq 4$ & $\mathrm{H}$ & 6.0913 & 3 & & \\
18 & Low & $\geq 4$ & $\mathrm{EH}$ & 10.3311 & 2 & & \\
\hline Risk比 & 3.2 & 4.9 & 2.9 & 46.0 & & 5.7 & \\
\hline
\end{tabular}

$\mathrm{N}$, normal ; high $(300-1000 \mathrm{u})$;

$\mathrm{EH}$, extremely high $(\geq 1000 \mathrm{u})$

1) Bリンパ腫で組織型がlow gradeのもの

ADM を含む治療法 (CHOP, CHOP-Bleo, $\mathrm{BACOP}$ ) と含まない治療法 (COPP, COP-Bleo, 
表 3.1982年以降に報告された代表的な治療法 (50例以上)

A) 欧米のび李ん性リンパ睡, unfavorable histologyに対 寸る効果

\begin{tabular}{|c|c|c|c|c|}
\hline & & & CR率(\%) & 再巺索 $(\%)$ \\
\hline $\mathrm{CHOP}$ & Armitage 5 & 1982 & $32 / 53(60.4)$ & $9 / 38(23.7)$ \\
\hline $\mathrm{CHOP}$ & Jones b & 1983 & $46 / 92(50.5)$ & \\
\hline VAP & Steward 5 & 1984 & $64 / 111(57.7)$ & $31 / 64(48.4)$ \\
\hline CHOP & Armitage 5 & 1984 & $38 / 65(58.5)$ & $15 / 38(39.5)$ \\
\hline CHOP & Gamsb & 1985 & $67 / 153(43.8)$ & \\
\hline CHOP & Jones 5 & 1985 & $194 / 388(50.0)$ & \\
\hline CHOP-Bleo & Jones 5 & 1983 & $47 / 92(51.1)$ & \\
\hline CHOP-Bleo & Jagannath 5 & 1985 & $43 / 61(70.5)$ & $13 / 43(30.2)$ \\
\hline CHOP-Bleo & Jagannaths & 1986 & $74 / 105(70.5)$ & $30 / 74(40.5)$ \\
\hline CHOP/CHOP-Bleo & Dixons & 1986 & $165 / 307(53.7)$ & $72 / 165(43.6)$ \\
\hline CHOP.P & Sullivan 5 & 1983 & $49 / 59(83.1)$ & $29 / 60(48.3)$ \\
\hline 6 剂(COP.BLAM) & Armitage $b$ & 1986 & $37 / 51(72.5)$ & $12 / 37(32.3)$ \\
\hline COMLA & Gaynor 5 & 1985 & $29 / 72(40.3)$ & \\
\hline NHL-3 & Koziner 5 & 1984 & $33 / 61(54,1)$ & \\
\hline M.BACOD & Skarin 5 & 1983 & $73 / 101(72.3)$ & $19 / 73(26.0)$ \\
\hline ProMACE MOPP & Fisher 5 & 1983 & $55 / 74 \quad(74.3)$ & $10 / 55(18.2)$ \\
\hline MACOP-B & Klimo b & 1985 & $51 / 61(83.6)$ & $5 / 51 \quad(9.8)$ \\
\hline$M(m)-B A C O P$ & Shipp 5 & 1985 & $87 / 121(71.9)$ & \\
\hline $\begin{array}{l}\text { CHOP/HOAP/MVP } \\
.16\end{array}$ & Cahanillas 5 & 1983 & $46 / 56(82.1)$ & \\
\hline LNH-80 & Coffier 5 & 1986 & $84 / 97(86.6)$ & $18 / 84(21.4)$ \\
\hline COP-BLAM III & Colman 5 & 1987 & $43 / 51(84.3)$ & \\
\hline ProMACE-CytaBOM & Fisher 5 & 1984 & $28 / 35(80.0)$ & \\
\hline
\end{tabular}

B）日本のT，B-リン八腫に対するVEPA，VEPAM㞠法 の効果

\begin{tabular}{c|l|c|c|c}
\hline & & & \multicolumn{2}{|c}{ CR率(\%) } \\
\cline { 4 - 5 } & & & $\mathrm{T}$ & $\mathrm{B}$ \\
\hline VEPA & lymphoma study group & 1982 & $15 / 41(36.6)$ & $37 / 59(62.7)$ \\
VEPA & F山正德他 & 1986 & $12 / 22(54.5)$ & $38 / 48(79.2)$ \\
VEPA & Shimoyama et al.(lymphoma & 1988 & $14 / 39(35.9)$ & $28 / 42(66.7)$ \\
VEPAM & study group) & 1988 & $18 / 42(42.9)$ & $33 / 40(82.5)$ \\
\hline
\end{tabular}

BCVP)のCR率に差はなく，共に70\%台と高い。

PCZとBLMは沪胞性リンバ腫に有効である。一 方, MTXの効果は少ない, 生存率や無再発率か ら, ADMを含む治療法の方がよい。

2）その他のT, Bリンパ腫,特にびまん性大細胞 型リンパ垕

最近の化学療法の成績を表 3 亿をとめて示す。 ADMを含亦初期の併用療法は第一期化学療法と 呼ばれ, CHOP, CHOP-Bleo, BACOP (D), VEPA，VEPA-Mなどがある、CHOP，VEPA療 法のCR率は50〜65\%である，BLMやPCZを加壳
たCHOP-B，CHOP-P，COP-BLAM，普通量の MTXを加えたVEPA-MのCR率は60～80\%台と 約 $10 \%$ 程高い。これらの治療法の治癒率は約 $40 \%$ である.

ADM とMTXの大量療法を主体とする第二世 代化学療法は $\mathrm{M}(\mathrm{m})-\mathrm{BACOD}(\mathrm{P}), \mathrm{MTX}-\mathrm{CHOP}$, ProMACE-MOPPなどがある. Colmann and Goldie $^{20)}$ の薬剤耐性を認識した新しい治療理論に 基づく強力な短期決戦型の治療法である第三世代 化学療法にはMACOP-B, LNH-80, ProMACECytoBOM III, ProMACE-CytoBOM IVなどがあ る。第二世代化学療法との差はMTXが中等量療 法で，非交差耐性の抗癌剂を意識的に併用し，短 期間に強力 (dose intensity) な治潦法を行ってい ることである。これらは専ら進行期びまん性大細 胞型リンパ腫に適用され，CR率は70～ $80 \%$ と一段 と高く, 再発率も $20 \%$ と低い.

CHOP, CHOP-Bleo, COP-BLAMなどの日本 での追試成績は，欧米以上の成果は得られていな い,日本では, VEPA療法とVEPA-M療法8)101-13), $\mathrm{ABEP}$ 療法 $^{21)}, \mathrm{AVCP} / \mathrm{ELMP}$ 療法 ${ }^{22)} と ゙ の$ 報告が ある。 T,Bリンパ腫に分けて検討したものでは, VEPAよりVEPA-MのほうがCR率は約10\%ほど 高い。またCR率はTリンパ腫では35～50\%と低 く, Bリンパ腫には 62 - $82 \%$ と高い.一方, ATL のCR率は $17 \%$ と低く、Tリンパ芽球性リンパ腫, IBL様Tリンパ腫も予後不良であるが，ATL以外 の末梢性 Tリンパ腫のCR率は67\%と高く，予後も Bリンパ腫に匹敵するほど良い、13).MTXを含む併 用療法はバーキットリンパ腫や予後の悪いびまん 性リンパ腫にも有効である．進行期であっても， 適切な薬物療法で治癒が期待できるものも多く， 強力な治療となるものでは，専門医に治療を任せ るべきである。

\section{3）ホジキン病の治療方針}

現状をまとめると，下記の様になる。

a) 病期 I，II のホジキン病は放射線治療で約 $75 \%$ 以上が治癒する。この放射線療法にMOPPを 併用すれば治瘾率は90\%以上に改善される14).

b) 病期III, IVのホジキン病は, MOPPやABVD 
療法で40～60\%が治癒する ${ }^{15)}$.この両者の併用療 法による交替療法（MOPP/ABVD）が最もよく， 治癒率はMOPP療法より約 $20 \%$ 高くなる ${ }^{16)}$.

c）MOPP療法で再発したホジキン病の治療で はABVD併用療法が有効である17).

\section{文献}

1）手島伸一，他：日本のホジキン病一国立がんセン タ一病院110例の検討一。 日絧会誌 $19: 347$, 1979.

2) 田島和雄, 他：ホジキン病の病理組織診断の問題 点. 日網会誌 $20: 149,1980$.

3) 本告 匡, 他: 九州, 筑紫地力に㧍ける悪性りン 八腫一病理学的研究一. 日血会誌 $44: 459,1981$.

4) 佐藤栄一：ホシキン病とT-cell malignancy. 病理 と臨林 $1: 382,1983$.

5）青笹克之，他：大阪地方の悪性リンバ腫Iホシシキ ン病. 日網会誌 $24: 105,1984$ 。

6) 下山正德, 末多恵一編集：白血病・リンハ腫. 図 説臨床「癌」シリーズ, No. 17, 1987.

7）下山正徳, 太田和雄：Bりンハ腫の予後因子と治 療, 日網会誌 $27: 329,1988$.

8) 下山正徳, 他：B-リンパ腫の化学療法 (VEPA療 法)一T-リソパ腫上の比較一。癌と化学療法 13 : $435,1986$.

9）下山正德，他：T-リンパ腫の予後因子、臨休血液 印刷中.

10) Lymphoma Study Group: Final results of cooperative study of VEPA therapy in advanced adult non-Hodgkin's lymphoma: Relation between $\mathrm{T}$ - or B-cell phenotype and response. Jpn J Clin Oncol 12:227, 1982.

11) Shimoyama $M$, et al. (Lymphoma study group 1981 1983): Chemotherapeutic results and prognostic factors of patients with advanced non-Hodgkin's lymphoma treated with VEPA or VEPA-M. J Clin Oncol 6:128, 1988.

12) Shimoyama $M$, et al. (Lymphoma study group
1981 1983): Major prognostic factors of adult patients with advanced $T$.cell lymphoma/leukemia. J Clin Oncol 6: 1088, 1988.

13) Shimoyama M, et al. (Lymphoma study group 1981 1983): Major prognostic factors of adult patients with advanced B-cell lymphoma treated with VEPA or VEPA-M. Jpn J Clin Oncol 18:113, 1988.

14) Hoppe RT: Stage I-II Hodgkin's disease: Current therapeutic options and recommendation. J Clin Oncol $62: 32,1983$.

15) Longo DL, et al.: Twenty years of MOPP therapy for Hodgkin's disease. J Clin Oncol 4 : 1295, 1986.

16) Santoro A, et al.: Long-term results of combined chemotherapy-radiotherapy approach in Hodgkin's disease: Superiority of ABVD plus radiotherapy versus MOPP plus radiotherapy. $\mathrm{J}$ Clin Oncol $5: 27,1987$.

17) Santoro A, et al. : Salvage chemotherapy in Hodgkin's disease irradiation failures: Superiority of doxorubicin containing regimens over MOPP. Cancer Treat Rep 70:343, 1986.

18）下山正徳：覀性リンパ腫の化学療法. 代謝 18 : 1051, 1981.

19）下山正德，他：非ホジキンリンパ腫とホジキン病 の化学潦法. 医学のあゆみ $141: 657,1987$.

20) Coldmann $G$, et al. : A mathematic model for relating the drug sensitivity of tumors to their spontaneous mutation rate. Cancer Treat Rep $63: 1727,1979$.

21）吉田 喬, 他：進行性非ホジンリンパ腫に対す るABEP療法。癌と化学療法 $13: 984,1986$.

22）山崎博之, 他：びまん性進行非ホジキンリンハ腫 に対するABVD/EMLP交替嘹法.日血会誌 49: 1404, 1986. 